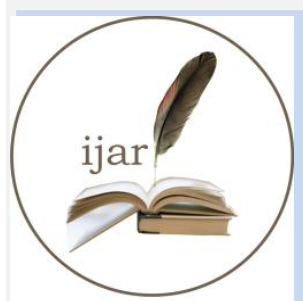

ISSN NO. 2320-5407

Journal Homepage: - www.journalijar.com INTERNATIONAL JOURNAL OF ADVANCED RESEARCH (IJAR)

Article DOI: $10.21474 /$ IJAR01/1426

DOI URL: http://dx.doi.org/10.21474/IJAR01/1426

RESEARCH ARTICLE

\title{
MILIUSA TOMENTOSA (ROXB.) J. SINCLAIR: WILD FOOD PLANT FOR LARVAL HOST OF BUTTERFLIES IN TRIBAL DOMINATED AREA OF ABU ROAD IN SIROHI DISTRICT OF RAJASTHAN, INDIA.
}

Meeta Sharma and Sangeeta Tripathi.

Arid Forest Research Institute, Jodhpur (Rajasthan)-342005.

\section{Manuscript Info}

Manuscript History

Received: 12 June 2016

Final Accepted: 19 July 2016

Published: August 2016

Key words:-

Butterfly, Tribal dominated area of Abu road, status species diversity.

\section{Abstract}

Abu Road is one of the tribal dominated area of Rajasthan famous for Garasia tribes who are unique in their ethno cultural heritage, far from the modern civilization and mostly depend on the forest and forest produce for their livelihood including the other tribes. These tribes are most backward and live in the interior forest. Livelihood systems in the study area is complex. Agriculture and daily labour are the major source of livelihood. People in the area work as daily labourer but also visit nearby areas in absence of the labour opportunity. This area comes under dry deciduous forest, common species in natural forest include Butea monosperma, Anogeissus latifolia, zizyphus spp., Azadirachta indica, Madhuca longifolia, Boswellia serrata, Manilkara hexandra, Diospyros melanoxylon, Phonix spp., Pithocellobium dulce, Annona squamosa and Miliusa tomentosa. Miliusa tomentosa (Roxb.) J. Sinclair is commonly known as Hoom. It is a large deciduous tree, growing up to $20 \mathrm{~m}$ tall. The fruits are edible and the wood is used for making cots in the region. Fruits are given to children to build up stamina and is also used to cure respiratory disorders. During the study the survey has been done and this tree is observed as the larval host plant for the various species of butterflies.

The butterflies play an important role as the pollinator, carries pollen from one flower to another. Their larvae act as the pest, injurious to various crops. Present study was carried out at tribal dominated area of Abu road of Sirohi district, Rajasthan, during May 2015 to May 2016 to record the species composition of butterflies. During this study a total of 16 species and 04 families were reported. The reported families Nymphalidae covered $37.5 \%$, Papilionidae $31.25 \%$, Danaidae $12.5 \%$ and Pieridae $18.75 \%$ biodiversity of butterflies of the study area. In Nymphalidae included, Junonia orithya, Junonia almana, Byblia ilithyia, Hypolimnas bolina, Hypolimnas misippus and Cynthia cardui. In Papilionidae included Graphium nomius, Graphium doson, Graphium Agamemnon, Graphium teredon and Charaxes psaphon. In Danidae included Danaus chrysippus and Danaus genutia. In Pieridae included Cepora nerissa, Catopsilia crocale and Colotis etrida. Species diversity index $\left(\mathrm{H}^{\prime}\right)$ was highest $(0.425)$ in case of family Nymphalidae compared to other. It is suggested that butterfly species diversity generally increases with increase in vegetation and declines with the 
increase in disturbance. A detail study is required for further exploration of butterfly fauna of tribal dominated area of Abu road of Sirohi district.

Copy Right, IJAR, 2016,. All rights reserved.

\section{Introduction:-}

The 1.4 million species on the earth planet, over 53\% are insects, while about 15,000-16,000 species of butterflies are known worldwide (Hassan,1994). Lepidoptera is one of the most wide spread and widely recognizable insect orders in the world. The term was coined by Linnaeus in 1735 and is derived from Ancient Greek (scale) and wing. Linnaeus in Systema Naturae(1758) recognized three divisions of the Lepidoptera: Papilio, Sphinxand Phalaena, with seven subgroups in Phalaena (Perveen and Ahmed, 2012).Butterflies are the most brightly colored insects belonging to order Lepidoptera of class insecta and it is the second largest order after Coleoptera. Adults of many Lepidopterans are most efficient pollinators as they suck the sap of Nectar by sucking mouth parts, while the caterpillars of many Lepidopterans defoliate various types of plants and causing severe damages to them (Kumar et al. 2013).Butterflies are the good indicators of environmental quality (Uniyal and Mathur, 1998; Dennis and Hardy, 2001). Changes in abundance and distribution of butterflies have been linked to a range of factors, including habitat loss and fragmentation; land use and climate change (Asher et al. 2001). Some species appear to be benefitting from climate warming and have expanded in both range and abundance (Fox et al. 2007). Species that use aposematism as an anti-predator strategy are expected to bemonomorphic for colour pattern, in order to facilitate avoidance learning by predators; if the aposematic prey is polymorphic, naïve predators will need to experience every colour form independently (Kumar et al. 2013). The Queen butterfly, Danaus chrysippus is a nymphalid butterfly which belongsto the subfamily Danainae. It is widely distributed throughout the old world tropics and subtropics. It is found in all habitats including deserts and mountains. However, it is primarily an open country butterfly (Kumar et al. 2013). The species is well adapted to human disturbance (Owen, 1970), since it is most abundant inhuman made habitats such as farms, gardens, waste land and roadsides. Danaus chrysippus does not form discrete populations and the long-lived adults range widely in search of nectar, pyrrolizidine alkaloid sources, mates and food-plants (Kumar et al. 2013). Moreover, it is a migratory butterfly which undergoes both short term and long-term movements (Smith \& Owen, 1997). Biological diversity is now increasingly recognized as a vital parameter to assess global and local environmental changes and sustainability of developmental activities. However, a systematic study of invertebrates particularly butterflies has not been carried out from the Abu road region. Vaghela et al., 2013 studied the Diversity Pattern of Butterfly Communities (Lepidoptera) at Mangrol Region of Kathiawar Peninsula, India, but there is no report on the diversity and status of butterfly species in the rest of the Saurashtra region. Therefore, in the present investigation an attempt has been made to study the diversity and status of butterfly fauna in tribal dominated area of Abu road, Sirohi district, Rajasthan. Miliusa tomentosa is commonly known as Hoom and in local language Umbiya. It is a large deciduous tree, growing up to $20 \mathrm{~m}$ tall. Bark is blackish brown. Leaves are thick leathery, ovate, oblong, $4-10 \mathrm{~cm}$ long, $2-5.5 \mathrm{~cm}$ broad, smooth above, softly hairy below, base rounded, margin entire, tip pointed, leaf-stalk 2-5 mm. Flowers are greenish, $1.5 \mathrm{~cm}$ across, solitary or in pairs opposite the leaf. Sepals are about $4 \mathrm{~mm}$ long, linear-lanceshaped. Petals are 3+3, abount $6 \mathrm{~mm}$ long, outer petals sepal-like, inner ones oblong to obovate. Fruits are dark purple, nearly spherical, 8-17 arranged in a ring, 2-3 cm across, stalk 1$1.5 \mathrm{~cm}$ long, seeds 3-4. Hoom is found in Rajasthan, Bihar, Odisha, Karnataka, Tamil Nadu, Maharashtra, Nepal and Srilanka. Flowering: May-June.

\section{Materials and methods:-}

\section{Collection sites:-}

The samples were collected from tribal dominated area of Abu road block of Sirohi district Rajsasthan, India (Figure 1, Pg.-6) during survey made at May 2015 to May 2016. 
Fig. 1:- Study area in Abu Road Block of Sirohi District in Rajasthan.

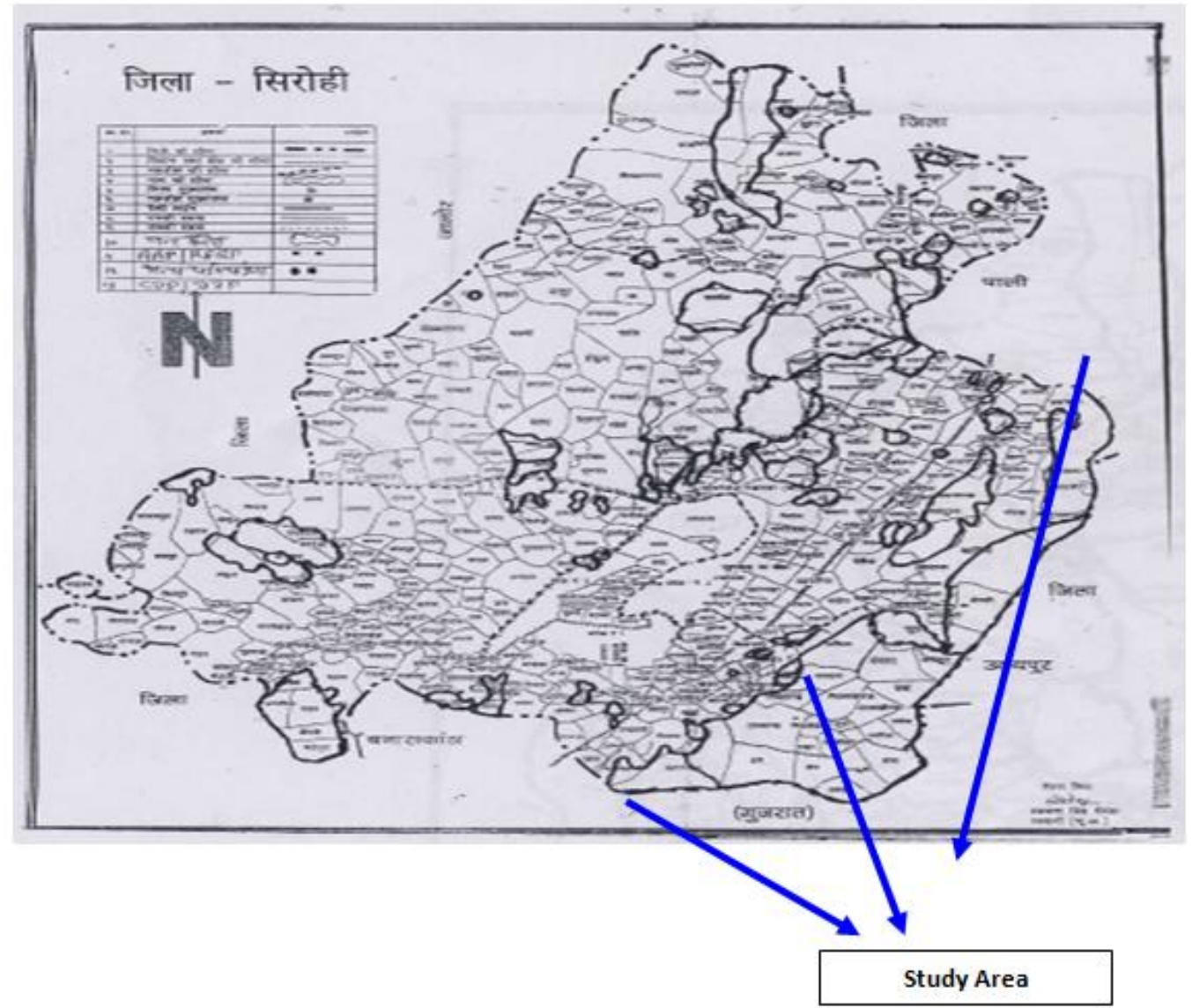

(Source : DSO, Sirohi)

\section{Collection of samples:-}

Adult butterflies were collected from the selected area by using a standard butterfly net. The collection of insects was carried out in the early hours of the day because butterflies are usually active at early sun rise, therefore, it was easy to observe and collect them. Butterflies have been put in ethyl acetate bottle for killing. Then they were placed on a board for stretching their wings to measure their wingspan and inserted the insect pin into their thoracic region. When their wings dried, they were arranged in the wooden box, in different rows with the phenolphthalein balls for the protection from pests. Butterflies were identified in the field using field guides by Wynter-Blyth (1957), Kunte (2000),Kehimkar (2008) and followed classification given by Gaonkar (1996). The species and seasonal diversity has been calculated by using "Shannon Wiener index".

\section{Result and Discussion:-}

During the present study a total of 50 individuals belonging to 16 species and 04 families were reported, out of 04 families, Nymphalidae was the most dominant family in terms of number of species and represented by 6 species followed by Papilionidae ( 5 species), Pieridae ( 3 species), and Danaidae ( 2 species) (Table $1 \& 2$, Pg.-7). In terms of number of individuals the family Nymphalidae was most dominant followed by Papilionidae, Pieridae and Danaidae (Table 2, Pg.-7). 
Table 1:- Taxonomic composition of Butterflies recorded from the study area. (Abbreviations: A - abundant, Ccommon, R- rare)

\begin{tabular}{|c|c|c|c|}
\hline S.No. & Taxonomic composition & Common name & Status \\
\hline \multicolumn{4}{|c|}{ Family Nymphalidae } \\
\hline 1. & Junonia orithya (Linnaeus 1758) & Blue Pansy & $\mathrm{C}$ \\
\hline 2. & Junonia almana (Linnaeus 1758) & Peacock Pansy & $\mathrm{C}$ \\
\hline 3. & Bybliai lithyia (Drury 1773) & Joker & $\mathrm{R}$ \\
\hline 4. & Hypolimnas bolina (Linnaeus 1758) & Great Eggfly & $\mathrm{C}$ \\
\hline 5. & Hypolimnas misippus (Linnaeus 1758) & DanaidEggfly & $\mathrm{R}$ \\
\hline 6. & Cynthia cardui (Linnaeus 1758) & Painted Lady C & $\mathrm{C}$ \\
\hline \multicolumn{4}{|c|}{ Family- Papilionidae } \\
\hline 7. & Graphium agamemnon & Tailed Jay or Green-spotted Triangle & $\mathrm{C}$ \\
\hline 8. & Graphium doson & Common Jay & $\mathrm{C}$ \\
\hline 9. & Graphium nomius & Spot Sword tail & $\mathrm{C}$ \\
\hline 10. & Graphium teredon & Narrow-banded Bluebottle & $\mathrm{C}$ \\
\hline 11. & Charaxes psaphon & Plain Tawny Rajah & $\mathrm{R}$ \\
\hline \multicolumn{4}{|c|}{ Family- Pieridae } \\
\hline 12. & Cepora nerissa (Fabricius 1775) & Common Gull & $\mathrm{R}$ \\
\hline 13. & Catopsilia crocale (Cramer 1775) & Common Emigrant & $\mathrm{C}$ \\
\hline 14. & Colotis etrida (Boisduval 1836) & Small Orange Tip & $\mathrm{C}$ \\
\hline \multicolumn{4}{|c|}{ Family Danaidae } \\
\hline 15. & Danaus chrysippus (Linnaeus 1758) & Plain tiger & A \\
\hline 16. & Danaus genutia (Cramer 1779) & Striped Tiger & $\mathrm{C}$ \\
\hline
\end{tabular}

Table 2:- Relative abundance, species composition and species diversity of Butterflies recorded from selected sampling site during the study period.

\begin{tabular}{|l|l|l|l|l|}
\hline S.No. & Family & No. of species & \% of species & Species Diversity (H') \\
\hline 1. & Nymphalidae & 06 & 37.5 & 0.425 \\
\hline 2. & Papilionidae & 05 & 31.25 & 0.505 \\
\hline 3. & Pieridae & 03 & 18.75 & 0.472 \\
\hline 4. & Danidae & 02 & 12.5 & 0.903 \\
\hline & Total & 16 & 100 & 2.305 \\
\hline
\end{tabular}

Gilbert and Singer (1975) have pointed out the availability of larval as well as adult food resources as a limiting factor in the occurrence and migration of butterflies. Five species are listed in the Wildlife (Protection) Act, 1972 (Anonymous, 1990) with each two species in Schedule I and II and one species in Schedule IV. Danaid eggfly (Hypolimnas misippus) is listed in Schedule I and II. In the present study Danaid eggfly recorded very rarely during the study period, while Blue Pansy (Junonia orithya), Great Eggfly (Hypolimnas bolina), Tailed jay (Graphium agamemnon), Common Jay (Graphium doson), Common Emigrant (Catopsiliacrocale) and Small Orange Tip (Colotisetrida) are occurred common in the sampling area (Table 1). Vaghela et al., 2013 has carried out studies on Diversity Pattern of Butterfly Communities in Mangrol Region of Kathiawar Peninsula, India. It is also reported in determining the pattern of butterfly community, relative abundance of butterfly and plants resources was an important aspect that characterizes butterfly community (Yamamoto et al. 2007). There was evidence that related groups of butterfly species associated with particular plants (as larva host plants or imago food plants) and that phenomenon was also found by Queiroz (2002).

\section{Conclusion:-}

From above study it was concluded that the Nymphalidae was the most dominant family in terms of number of species followed by Papilionidae, Pieridae and Danaidae, while in terms of number of individuals the family Pieridae was most dominant followed by Nymphalidae, Papilionidae and Danaidae. 


\section{References:-}

1. Anonymous: The Indian Wildlife (Protection) Act 1772. 1990. Nataraj Publisher, Dehradun.

2. Asher J., Warren M., Fox R. et al. 2001. The Millennium Atlas of Butterflies in Britain and Ireland.Oxford University Press, Oxford.

3. Dennis R. B. and Hardy P. B. 2001.Loss rate of butterfly. Biodiversityand conservation 99:263-276.

4. Fox R., Warren M.S., Asher J., Brereton T.M. and Roy D.B. 2007. The state of Britain's butterflies2007. Butterfly Conservation and the Centre for Ecology and Hydrology, Wareham, Dorset.

5. Gaonkar H.1996.Butterflies of the Western Ghats with notes on those of Sri Lanka. A report to Centre for Ecological Sciences, Indian Institute of Science, Bangalore; Zoological Museum, Copenhagen and Natural History Museum, London.

6. Gilbert L.E. and Singer M.C.1975.Butterfly ecology. Ann. Rev. Ecol. Syst., 6, 365-397.

7. Hassan, S. A., 1994. Butterflies of Islamabad and Murree Hills. Asian Study Group, Islamabad 1-68.

8. Kumar S., Khamashon L., Pandey P., Chaudhary R., Nath P., Awasthi S. \&Joshi P.C. 2013. Community Composition and Species Diversity ofButterfly Fauna with in GurukulaKangri Vishwavidyalaya Campus. Journal of Entomology and Zoology Studies. 1 (6): 66-69.

9. Kunte K.2000. Butterflies of peninsular India (India: A Lifescape). Hyderabad: Universities press (India) Limited p. 272.

10. Kehimkar I.2008.Book of Indian Butterflies.Bombay Natural History Society. Mumbai and Delhi: Oxford University Press p. 513.

11. Owen D. F. 1970. Mimetic polymorphism and the palatability spectrum.Oikos 21: 333- 336.

12. Perveen F. and Ahmad A.2012.Exploring Butterfly Fauna (Lepidoptera) of Kohat, Khyber Pakhtunkhwa, Pakistan.SOAJ Entomological Studies.1:119-129

13. Queiroz J. M. 2002. Host plant use among closely related Anaea butterfly species (Lepidoptera, Nymphalidae, Charaxinae). Braz J Biol 62: 657-663.

14. Smith D. A. S. and Owen D. F. 1997. Colour genes as markers for migratory activity: The butterfly Danaus chrysippus in Africa. Oikos 78: 127-135.

15. Uniyal V. P. andMathur P. K. Diversity of butterflies in thegreat Himalayan national park, Western Himalaya.Ind J Forestry. 21(2):150-155.

16. Vaghela A., Bhadja P. and Trivedi V.2013. Diversity Pattern of Butterfly Communities (Lepidoptera) at Mangrol Region of Kathiawar Peninsula, India. Asian Journal of Biodiversity. 4: 99-118.

17. Wynter-Blyth M. A.1957.Butterflies of the Indian Region. Bombay Natural History Society, Mumbai.

18. Yamamoto N., Yokoyama J. and Kawata M. 2007. Relative resource abundance explains butterfly biodiversity in island communities. PNAS 104: 10524-10529. 